\title{
An Analytical Study on the Relationship between Dividend Policy and Market Capitalization: Case of Indian IT Companies
}

\author{
Debabrata Das ${ }^{1}$, Souris Bhattacharya ${ }^{2}$ \\ ${ }^{I}$ (Assistant Professor, Bengal School of Technology and Management, India) \\ ${ }_{2}^{2}$ (Assistant Professor, Bengal School Of Technology and Management, India)
}

\begin{abstract}
In the field of security analysis and portfolio management the prime interest of the researchers is the maximization of the return of the investors. Return on investment is important but, there are certain other parameters which needs equal highlights. Dividend decision is such an important parameter which influences investors' return. Dividend decision depends on many factors, including bt not limited to market capitalization of the firm. Different levels of research had already been conducted to establish relationship between market capitalisation and dividend payout, throughout the world for the past two decades. Despite that, in Indian context more analysis should be there to find relationship between market capitalization and dividend payout from different angles. One such effort has been carried out by focusing the top IT companies (listed in BSE) by considering their last five years market capitalization and dividend payout in the indian context. This paper focuses on the developing relationship between market capitalization and dividend payout of top IT companies in India from different perspectives.
\end{abstract}

Keywords: Market capitalization, Dividend payout

\section{Introduction}

Researchers of security analysis and portfolio management, in most of the cases want to focus on rate of return or return on investment of the investors. That is why lots of emphasis has been put on finding the factors on which portfolio return depends. New methods and terminology have been developed to estimate and predict investors' rate of return. This is a general trend across the globe and much important contribution has been made in the literature in this regard. Rate of return or return on investors' money or portfolio return is definitely very important from research point of view. But research should not be confined within the periphery of investors' return. That is why newer areas or newer interpretation of the existing relationship between the established parameters should be explored. Establishment of relationship between parameters should not be limited to finding the one to one value based analysis. Rather the focus should be exploring multivariate perspectives like analyzing the variability etc. should be explored. This type of research is important for better interpretation of the existing parameters and the interrelationship between them in order to enrich the literature.

\section{Objective}

The objective of this paper is to establish relationship between market capitalization and dividend payout. Relationship between these two parameters should be established from various perspectives like absolute relationship, relationship between the variables in terms of their growth rate and variation between the variables in terms of their variation.

\section{III. literature Review}

Authors upheld the importance of Market Capitalization as a fundamental parameter for analysis. On the basis of the definition of a complex market ( a market that is not fully segmented as well as not fully integrated ), they also suggest that valuation analysis should not be confined to Dividend Discount Model but it should also consider Market Capitalization along with other parameters.[1] Examining the relationship between Market Capitalization \& Dividend Payout, Mian Sajid Nazir, Allah Rakha, Muhammad Musarrat Nawaz proposed that both are significantly related. Their research focused on 68 firms from nonfinancial sector listed at KSE-100 index for the period of five years from 2006-2010 \& they suggested that corporate payout policy has strong relationship with market capitalization [2]. A recent study made by O.O.John on firms listed in Nairobi Securities Exchange also shows a clear relationship between Dividend payout Ratio and the market capitalization of the firms [3]. A study on average rank correlation between various characteristics for NYSE \& AMEX stocks shows negative correlation between Dividend Yield \& Market Capitalization [4]. M. Oluwatoyin \& O.O. Gbadebo researched on one of the largest confectionary companies in Nigeria \& found that " the performance of a company in terms of turnover, profit after tax and dividends and the value of a company in the stock exchange in terms of price index and market capitalization are dependent on one another." [5] 
Author strongly believes that market Capitalization should be a controlling variable as a measure of size in dividend policy [6]. Finding of the analysis done by Dr. Vijay Kandpal and Prof. P C Kavidayal reveals that dividend policy of the firm has impact on the market price of the share. Their research focused on 15 public sector banks and 15 private sector banks in India, which suggested that there is a mixed outcome in the result, as the researchers have observed that there is a positive correlation between dividend policy and value of share for some banks and negative correlation for the remaining [7]. The study conducted by Lilian Luvembe, Mungai John Njangiru, Dr. Eddie Simiyu Mungami on 10 banks listed in Nairobi Securities Exchange proposed a posistive correlation between dividend payout and market value of the shares of the banks. The study also reveals a positive impact of capital structure, corporate earnings and capital market investment on the market value of the shares[8].

The research conducted by Abdullah Al Masum on the listed banks in the Dhaka Stock Exchange proposes that, dividend yield and retention ratio is negatively correlated with the market price of the shares, while earnings per share and return on equity have positive impact on the same. [9] Observing 13 companies listed in Dar Es Salaam Stock Exchange, authors proposed that, dividend payout ratio, dividend yield and earnings per share is negatively correlated to the market price of the share, while the price earning ratio is highly correlated to the market price of share.[10] Observation of the authors reveals a negative correlation between dividend policy and share price volatility, while asset growth, earning volatility and long term debt have positive correlation with share price volatility. [11]

The research reveals the impact of EPS as an accounting variable on the value of equity share. Value of share price is partially dependent on EPS. [12]

\section{Research methodology}

Past research on security analysis shows that secondary data collected from historical records is of prime importance. As the objective of this paper is to establish relationship between dividend payout and market capitalization from different perspective, correlation is the preferred statistical method for this purpose.

\section{Types of data and its nature}

Secondary data consists of the market capitalization and dividend paid of top eight IT companies in India has been collected from moneycontrol.com for five years from 2010-11 to 2014-15. Initially the closing price of the equity share of the companies on the last day of the financial year has been collected and it has been multiplied by number of shares outstanding.

\section{Research design}

To fulfill the objective of this paper relationship between market capitalization and dividend paid has been established from three different perspectives.

2.1. The absolute figure of market capitalization and dividend paid has been compared using ordinary correlation or Pearson's correlation method.

2.2. The year on year growth rate of market capitalization and dividend paid have been calculated. Then on the basis of the growth rate of dividend and market capitalization, companies have been ranked and then Spearman's rank correlation method is used to establish the relationship between these two variables with respect to the rank of the growth rate.

2.3. The variance of the market capitalization and dividend paid has been calculated and on the basis of the variance, different ranks have been given to the companies. Then, Spearman's rank correlation method is used to obtain the relationship between market capitalization and dividend paid in terms of variability.

All the arithmetic calculations required for this research have been carried out using MS Excel. Statistical calculations and analysis have been carried out using the statistixl software.

\section{Figures and Tables \\ Correlation Coefficient between Market Capitalization and Total Dividend Declared for individual companies}

Table No: I for TCS

\begin{tabular}{|l|l|l|l|l|}
\hline SL NO. & FINANCIAL YEAR & $\begin{array}{l}\text { Market Capitalization of TCS } \\
\text { Ltd }(\text { in bn INR)(X) }\end{array}$ & $\begin{array}{l}\text { Total Dividend Declared } \\
\text { in bn INR)(Y) }\end{array}$ & $\begin{array}{l}\text { Correlation } \\
\text { Coefficient }\end{array}$ \\
\hline 1 & $2010-11$ & 2314 & 39 & $\mathbf{0 . 8 2 9}$ \\
\hline 2 & $2011-12$ & 2285 & 33 \\
\hline 3 & $2012-13$ & 3076 & 48 \\
\hline 4 & $2013-14$ & 4168 & 48 & 146 \\
\hline 5 & $2014-15$ & 4988 & 146 \\
\hline
\end{tabular}




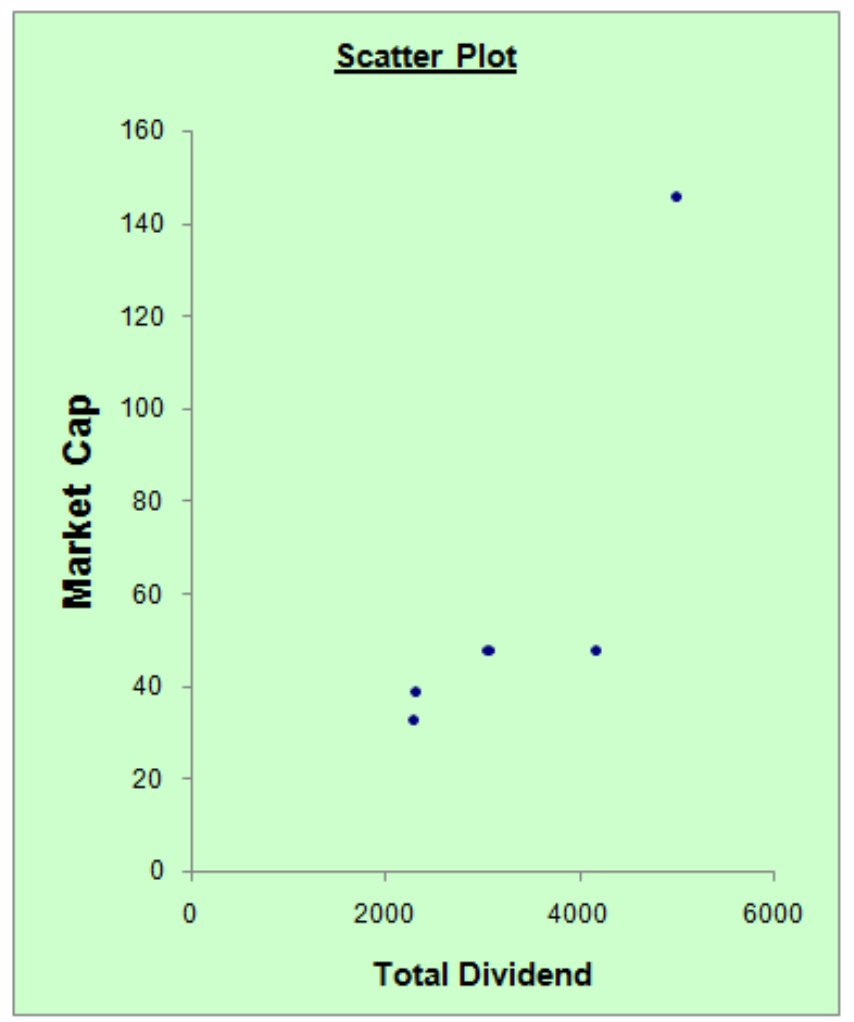

Table No: II for Infosys

\begin{tabular}{|l|l|l|l|l|}
\hline SL NO. & $\begin{array}{l}\text { FINANCIAL } \\
\text { YEAR }\end{array}$ & $\begin{array}{l}\text { Market Capitalization } \\
\text { of Infosys Ltd ( in bn } \\
\text { INR)(X) }\end{array}$ & $\begin{array}{l}\text { Total Dividend Declared ( in } \\
\text { bn INR)(Y) }\end{array}$ & $\begin{array}{l}\text { Correlation } \\
\text { Coefficient }\end{array}$ \\
\hline 1 & $2010-11$ & 1858 & 31.56 & $\mathbf{0 . 9 2 6}$ \\
\hline 2 & $2011-12$ & 1645 & 20.09 & \\
\hline 3 & $2012-13$ & 1659 & 26.99 & \\
\hline 4 & $2013-14$ & 1874 & 26.99 & 41.71 \\
\hline 5 & $2014-15$ & 2546 & & \\
\hline
\end{tabular}

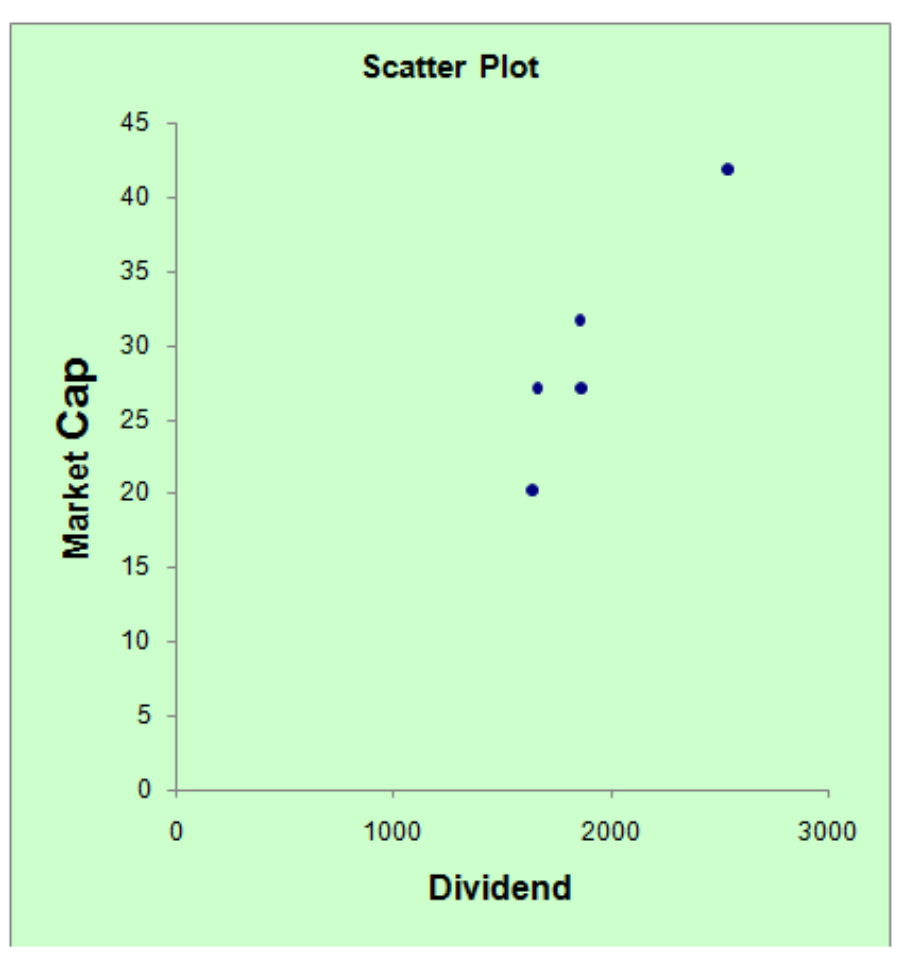


Table No: III for WIPRO

\begin{tabular}{|c|c|c|c|c|}
\hline SL NO. & FINANCIAL YEAR & $\begin{array}{l}\text { Market Capitalization of } \\
\text { Wipro Ltd ( in bn } \\
\text { INR)(X) }\end{array}$ & $\begin{array}{l}\text { Total Dividend Declared ( in } \\
\text { bn INR)(Y) }\end{array}$ & $\begin{array}{l}\text { Correlation } \\
\text { Coefficient }\end{array}$ \\
\hline 1 & $2010-11$ & 1174 & 11.75 & \multirow[t]{5}{*}{0.905} \\
\hline 2 & $2011-12$ & 1079 & 14.73 & \\
\hline 3 & $2012-13$ & 1077 & 14.75 & \\
\hline 4 & 2013-14 & 1338 & 19.7 & \\
\hline 5 & $2014-15$ & 1550 & 24.66 & \\
\hline
\end{tabular}

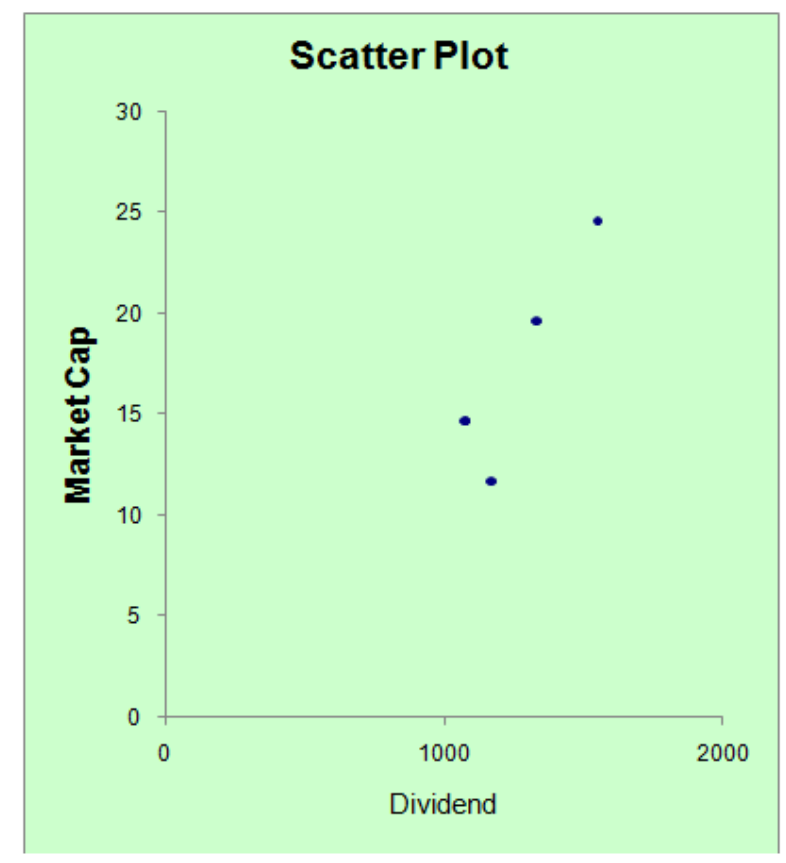

Table No: IV for HCL

\begin{tabular}{|l|l|l|l|l|}
\hline SL NO. & $\begin{array}{l}\text { FINANCIAL } \\
\text { YEAR }\end{array}$ & $\begin{array}{l}\text { Market Capitalization of HCL } \\
\text { Ltd }(\text { in bn INR)(X) }\end{array}$ & $\begin{array}{l}\text { Total Dividend Declared } \\
\text { in bn INR)(Y) }\end{array}$ & $\begin{array}{l}\text { Correlation } \\
\text { Coefficient }\end{array}$ \\
\hline 1 & $2010-11$ & 164 & 3.73 & $\mathbf{0 . 9 4 5}$ \\
\hline 2 & $2011-12$ & 167 & 6.88 & \\
\hline 3 & $2012-13$ & 277 & 9.7 & 12.54 \\
\hline 4 & $2013-14$ & 487 & 20.09 & \\
\hline 5 & $2014-15$ & 1377 &
\end{tabular}

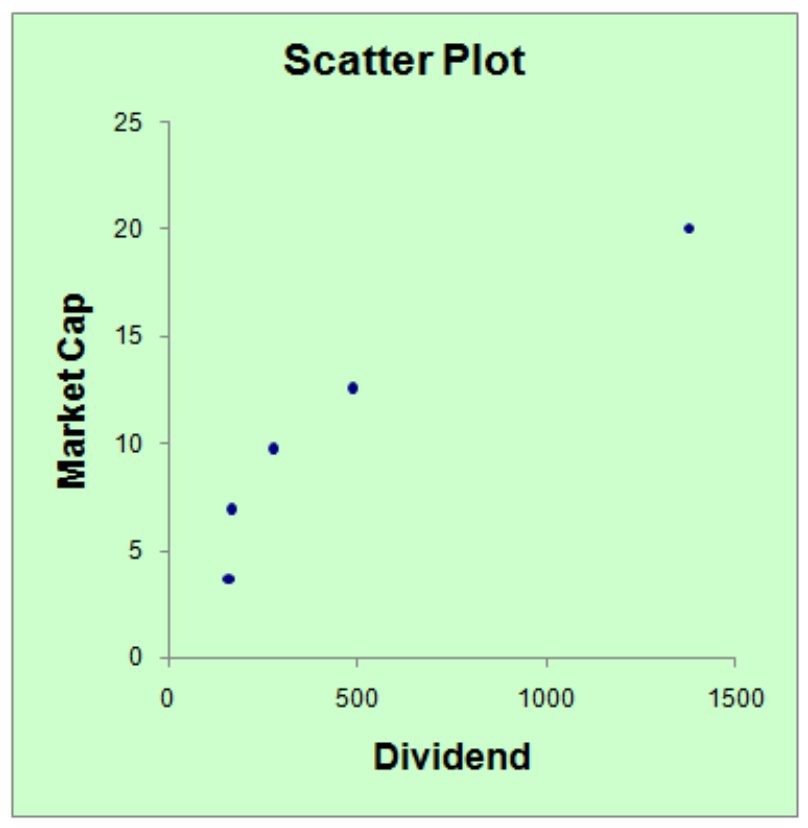


Table No: $\mathbf{V}$ for Tech Mahindra

\begin{tabular}{|l|l|l|l|l|}
\hline SL NO. & $\begin{array}{l}\text { FINANCIAL } \\
\text { YEAR }\end{array}$ & $\begin{array}{l}\text { Market Capitalization of } \\
\text { Tech Mahindra Ltd (in bn } \\
\text { INR)(X) }\end{array}$ & $\begin{array}{l}\text { Total Dividend Declared ( } \\
\text { in bn INR)(Y) }\end{array}$ & $\begin{array}{l}\text { Correlation } \\
\text { Coefficient }\end{array}$ \\
\hline 1 & $2010-11$ & 21.28 & 0.428 & \multirow{0}{*}{$\mathbf{0 . 9 9 4}$} \\
\hline 2 & $2011-12$ & 22.93 & 0.503 & \\
\hline 3 & $2012-13$ & 33.92 & 0.509 & \\
\hline 4 & $2013-14$ & 104.74 & 4.669 & \\
\hline 5 & $2014-15$ & 604.76 & & \\
\hline
\end{tabular}

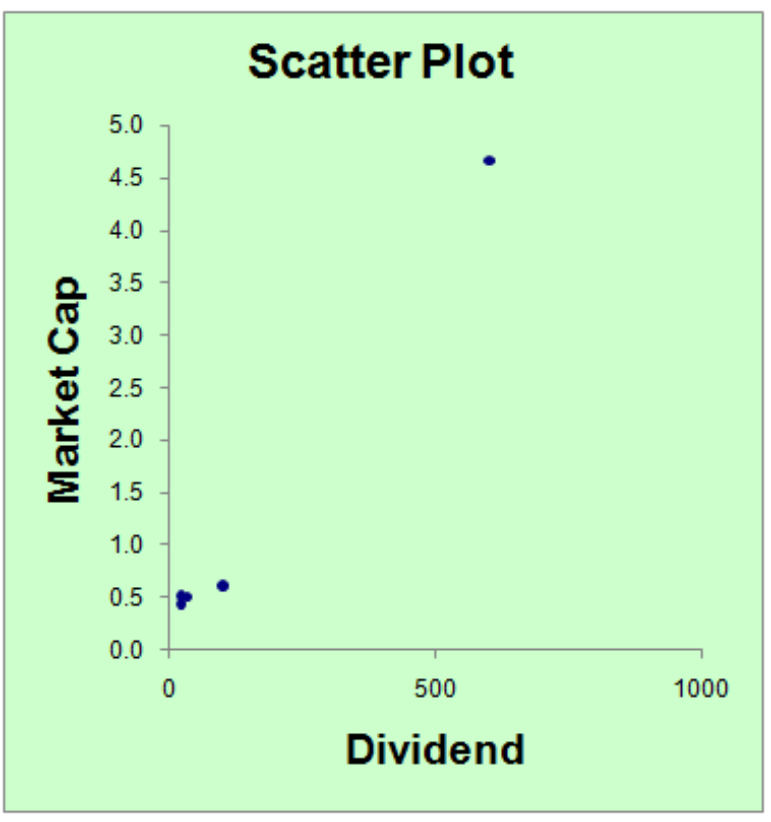

Table No: VI for MPhasis

\begin{tabular}{|l|l|l|l|l|}
\hline SL NO. & FINANCIAL YEAR & $\begin{array}{l}\text { Market Capitalization of } \\
\text { MPhasis Ltd (in bn INR)(X) }\end{array}$ & $\begin{array}{l}\text { Total Dividend Declared Correlation } \\
\text { (in bn INR)(Y) }\end{array}$ & $\begin{array}{l}\text { Coefficient } \\
\text { Cont }\end{array}$ \\
\hline 1 & $2010-11$ & 87.28 & 0.839 & $\mathbf{- 0 . 2 5 3}$ \\
\hline 2 & $2011-12$ & 84.94 & 1.365 & \\
\hline 3 & $2012-13$ & 82.36 & 3.571 & 3.571 \\
\hline 4 & $2013-14$ & 84.92 & 1.47 & \\
\hline 5 & $2014-15$ & 80.32 & & \\
\hline
\end{tabular}

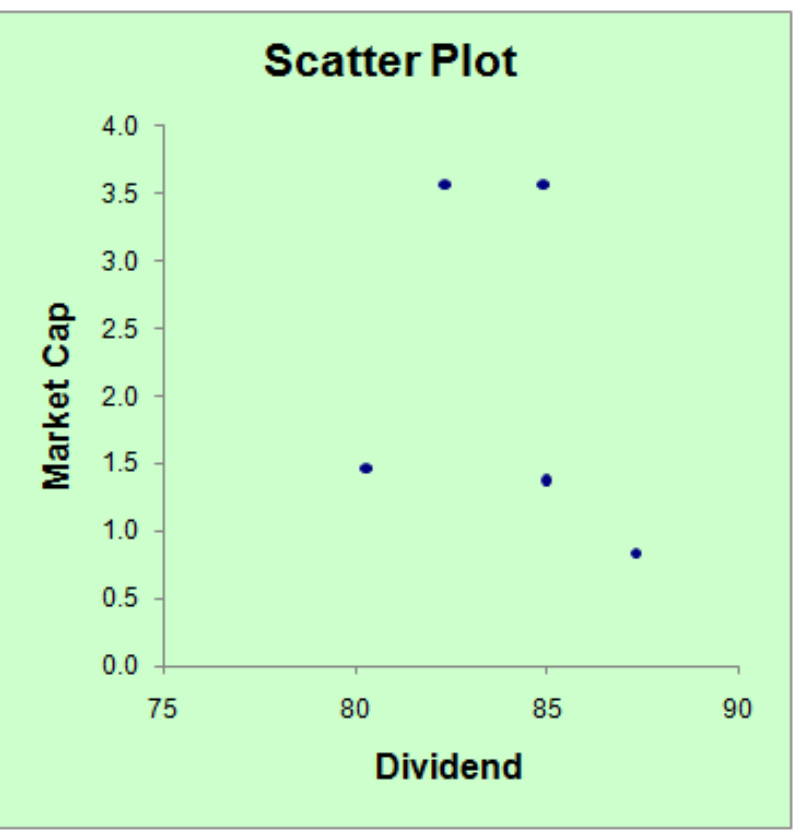


Table No: VII for Mindtree

\begin{tabular}{|l|l|l|l|l|}
\hline SL NO. & $\begin{array}{l}\text { FINANCIAL } \\
\text { YEAR }\end{array}$ & $\begin{array}{l}\text { Market Capitalization of } \\
\text { Mindtree Ltd in bn } \\
\text { INR)(X) }\end{array}$ & $\begin{array}{l}\text { Total Dividend Declared } \\
\text { (in bn INR)(Y) }\end{array}$ & $\begin{array}{l}\text { Correlation } \\
\text { Coefficient }\end{array}$ \\
\hline 1 & $2010-11$ & 3.933 & 0.128 & \multirow{0}{*}{$\mathbf{0 . 5 2 9}$} \\
\cline { 1 - 3 } & $2011-12$ & 4.941 & 0.15 & \\
\cline { 1 - 2 } & $2012-13$ & 9.466 & 0.141 & \\
\hline 5 & $2013-14$ & 13.74 & 0.996 & 0.708 \\
\hline
\end{tabular}

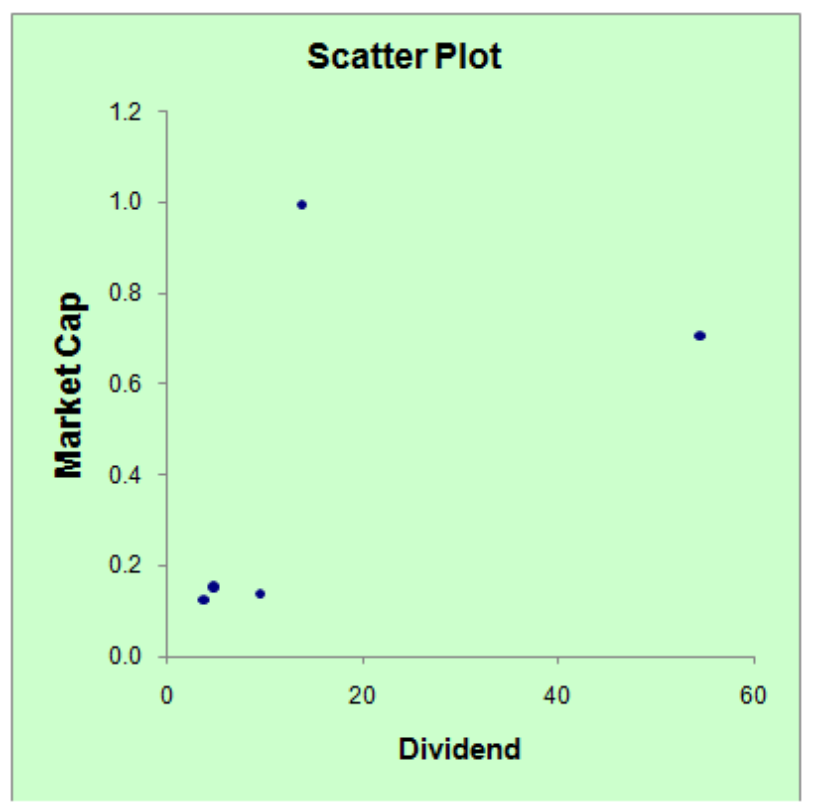

Table No: VIII for Hexaware

\begin{tabular}{|l|l|l|l|l|}
\hline SL NO. & $\begin{array}{l}\text { FINANCIAL } \\
\text { YEAR }\end{array}$ & $\begin{array}{l}\text { Market Capitalization } \\
\text { of Hexaware Ltd }(\text { in } \\
\text { bn INR)(X) }\end{array}$ & $\begin{array}{l}\text { Total Dividend Declared } \\
\text { (in bn INR)(Y) }\end{array}$ & $\begin{array}{l}\text { Correlation } \\
\text { Coefficient }\end{array}$ \\
\hline 1 & $2010-11$ & 9.57 & 0.43 & \multirow{0}{*}{0.438} \\
\hline 2 & $2011-12$ & 34.32 & 0.58 & \\
\hline 3 & $2012-13$ & 25.17 & 1.58 & \\
\hline 4 & $2013-14$ & 45.14 & 2.81 & \\
\hline 5 & $2014-15$ & 94.06 & & \\
\hline
\end{tabular}

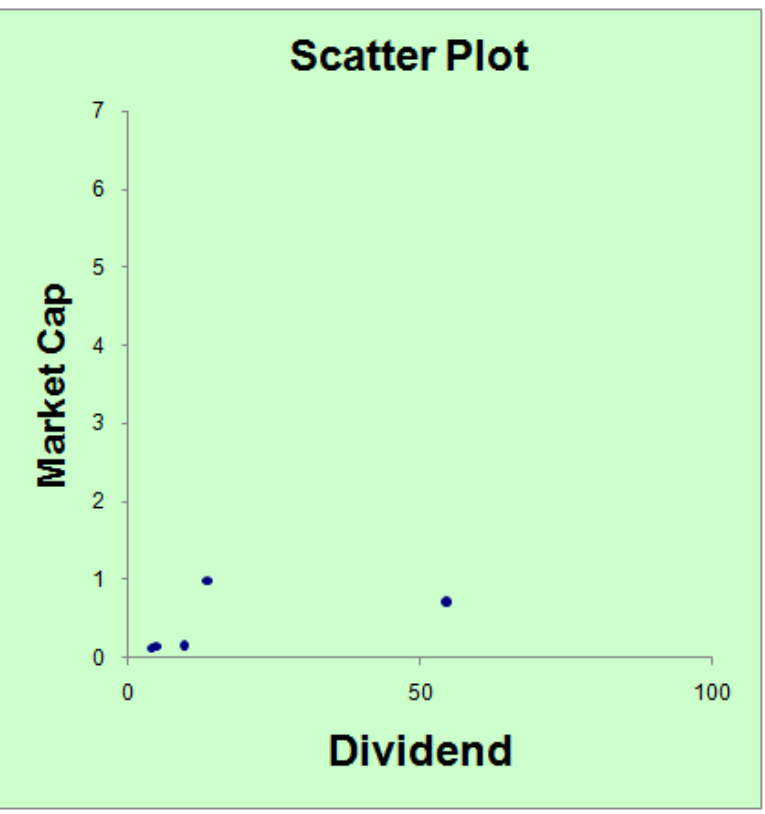


CV of M-Cap and their rank

\begin{tabular}{|l|l|l|l|l|l|}
\hline Sl. No. & Name of Companies & Mean Market Cap & $\begin{array}{l}\text { Standard Deviation } \\
\text { of M-Cap }\end{array}$ & CV of M-Cap & Rank \\
\hline 1 & TCS & 3366.200 & 1186.745 & 35.25 & $\mathbf{5}$ \\
\hline 2 & infosys & 1916.400 & 367.939 & 19.19 & $\mathbf{6}$ \\
\hline 3 & wipro & 1243.600 & 201.547 & 16.2 & $\mathbf{7}$ \\
\hline 4 & HCL technologies & 494.400 & 510.552 & 103.266 & $\mathbf{3}$ \\
\hline 5 & Tech mahindra & 157.526 & 252.370 & 160.208 & $\mathbf{1}$ \\
\hline 6 & Mphasis & 83.964 & 2.679 & 3.19 & $\mathbf{8}$ \\
\hline 7 & Mindtree & 17.336 & 21.194 & 122.25 & $\mathbf{2}$ \\
\hline 8 & Hexaware technologies & 41.652 & 32.068 & 76.99 & $\mathbf{4}$ \\
\hline
\end{tabular}

\section{CV of dividend and their rank}

\begin{tabular}{|l|l|l|l|l|l|}
\hline Sl. No. & $\begin{array}{l}\text { Name of } \\
\text { Companies }\end{array}$ & Mean Dividend & $\begin{array}{l}\text { Standard Deviation of } \\
\text { Dividend }\end{array}$ & CV of Dividend & Rank \\
\hline 1 & TCS & 62.800 & 46.944 & 74.75 & $\mathbf{4}$ \\
\hline 2 & infosys & 29.468 & 7.976 & 27.06 & $\mathbf{8}$ \\
\hline 3 & wipro & 17.118 & 5.091 & 29.74 & $\mathbf{7}$ \\
\hline 4 & HCL technologies & 10.588 & 6.238 & 58.91 & $\mathbf{6}$ \\
\hline 5 & Tech mahindra & 1.343 & 1.861 & 138.57 & $\mathbf{1}$ \\
\hline 6 & Mphasis & 2.163 & 1.307 & 60.42 & $\mathbf{5}$ \\
\hline 7 & Mindtree & 0.425 & 0.403 & 94.82 & $\mathbf{3}$ \\
\hline 8 & $\begin{array}{l}\text { Hexaware } \\
\text { technologies }\end{array}$ & 2.246 & 2.211 & 98.44 & $\mathbf{2}$ \\
\hline
\end{tabular}

Market capitalization growth rate and its rank

\begin{tabular}{|l|l|l|l|l|l|l|l|}
\hline Name of the company & $\mathbf{2 0 1 0 - 1 1}$ & $\mathbf{2 0 1 1 - 1 2}$ & $\mathbf{2 0 1 2 - 1 3}$ & $\mathbf{2 0 1 3 - 1 4}$ & $\mathbf{2 0 1 4 - 1 5}$ & $\begin{array}{l}\text { Avg Growth } \\
\text { Rate }\end{array}$ & Rank \\
\hline TCS & 51.45 & -1.24 & 34.59 & 35.51 & 19.68 & 28.00 & $\mathbf{6}$ \\
\hline infosys & 395.36 & -11.49 & 0.87 & 12.92 & 35.88 & 86.71 & $\mathbf{3}$ \\
\hline wipro & 88.54 & -8.05 & -0.25 & 24.29 & 15.83 & 24.07 & 7 \\
\hline HCL technologies & 35.12 & 1.91 & 65.87 & 75.47 & 183.03 & 72.28 & $\mathbf{5}$ \\
\hline Tech mahindra & -18.46 & 7.78 & 47.91 & 208.76 & 477.37 & 144.67 & $\mathbf{1}$ \\
\hline Mphasis & -32.98 & -2.67 & -3.03 & 3.10 & -5.42 & -8.20 & $\mathbf{8}$ \\
\hline Mindtree & -32.38 & 25.63 & 91.58 & 45.18 & 297.33 & 85.47 & $\mathbf{4}$ \\
\hline Hexaware technologies & 95.20 & 258.43 & -26.65 & 79.32 & 108.36 & 102.93 & $\mathbf{2}$ \\
\hline
\end{tabular}

Dividend Growth Rate and its rank

\begin{tabular}{|l|l|l|l|l|l|l|l|}
\hline $\begin{array}{l}\text { Name Of The } \\
\text { Company }\end{array}$ & $\mathbf{2 0 1 0 - 1 1}$ & $\mathbf{2 0 1 1 - 1 2}$ & $\mathbf{2 0 1 2 - 1 3}$ & $\mathbf{2 0 1 3 - 1 4}$ & $\mathbf{2 0 1 4 - 1 5}$ & $\begin{array}{l}\text { Average } \\
\text { Growth Rate }\end{array}$ & \begin{tabular}{l} 
Rank \\
\hline TCS
\end{tabular} \\
\hline infosys & 81.82 & -15.00 & 47.06 & 0.00 & 200.00 & 62.78 & $\mathbf{4}$ \\
\hline wipro & 134.04 & -36.36 & 34.29 & 0.00 & 55.32 & 37.46 & $\mathbf{6}$ \\
\hline HCL technologies & 100.00 & -25.00 & 0.00 & 33.33 & 25.00 & 26.67 & $\mathbf{8}$ \\
\hline Tech mahindra & 37.50 & 81.82 & 40.00 & 28.57 & 66.67 & 50.91 & $\mathbf{5}$ \\
\hline Mphasis & 350.00 & 14.29 & 0.00 & 25.00 & 300.00 & 137.86 & $\mathbf{2}$ \\
\hline Mindtree & 14.29 & 62.50 & 161.54 & 0.00 & -58.82 & 35.90 & $\mathbf{7}$ \\
\hline $\begin{array}{l}\text { Hexaware } \\
\text { technologies }\end{array}$ & 114.29 & 33.33 & 35.00 & 262.96 & -51.79 & 78.76 & $\mathbf{3}$ \\
\hline
\end{tabular}

Rank Correlation coefficient between growth rate of $M$-cap and dividend

\begin{tabular}{|l|l|l|l|l|}
\hline Sl. No & Name Of The Company & $\begin{array}{l}\text { Rank As Per M-Cap } \\
\text { Growth Rate }\end{array}$ & $\begin{array}{l}\text { Rank As Per Dividend } \\
\text { Growth Rate }\end{array}$ & $\begin{array}{l}\text { Rank } \\
\text { Coefficient }\end{array}$ \\
\hline 1 & TCS & $\mathbf{6}$ & $\mathbf{4}$ & $\mathbf{0 . 6 9}$ \\
\hline 2 & Infosys & $\mathbf{3}$ & $\mathbf{6}$ & $\mathbf{8}$ \\
\hline 3 & wipro & $\mathbf{7}$ & $\mathbf{5}$ \\
\hline 4 & HCL technologies & $\mathbf{5}$ & $\mathbf{2}$ \\
\hline 5 & Tech mahindra & $\mathbf{1}$ & $\mathbf{7}$ \\
\hline 6 & Mphasis & $\mathbf{8}$ & $\mathbf{1}$ & $\mathbf{3}$ \\
\hline 7 & Mindtree & $\mathbf{4}$ & $\mathbf{3}$ \\
\hline 8 & Hexaware technologies & $\mathbf{2}$ &
\end{tabular}




\section{Rank Correlation between CV of M-cap and CV of Dividend}

\begin{tabular}{|c|c|c|c|c|}
\hline Sl. No & $\begin{array}{l}\text { Name Of The } \\
\text { Company }\end{array}$ & $\begin{array}{l}\text { Rank As Per Cv Of } \\
\text { M-Cap }\end{array}$ & $\begin{array}{l}\text { Rank As Per Cv } \\
\text { Of Div. }\end{array}$ & $\begin{array}{l}\text { Rank Correlation } \\
\text { Coefficient }\end{array}$ \\
\hline 1 & TCS & 5 & 4 & \multirow[t]{8}{*}{0.667} \\
\hline 2 & infosys & 6 & 8 & \\
\hline 3 & wipro & 7 & 7 & \\
\hline 4 & HCL technologies & 3 & 6 & \\
\hline 5 & Tech mahindra & 1 & 1 & \\
\hline 6 & Mphasis & 8 & 5 & \\
\hline 7 & Mindtree & 2 & 3 & \\
\hline 8 & $\begin{array}{l}\text { Hexaware } \\
\text { technologies }\end{array}$ & 4 & 2 & \\
\hline
\end{tabular}

\section{Data analysis and interpretation}

1.1. First level analysis with absolute figures

Last five years; market capitalization and total dividend declared has been compared using Pearson's ordinary correlation method. The result shows that TCS, Infosys, Wipro, Tech Mahindra, HCL have very high correlation coefficient. This shows that for these companies market capitalization and dividend declared is positively correlated. On the other hand, Mindtree and Hexaware have low level of correlation between market capitalization and dividend, while MPhasis has negative correlation. This shows that out of top eight companies, five companies have strong correlation between market capitalization and dividend paid. This result is also evident from the scatter plot of the result.

\subsection{Second level analysis}

The descriptive statistics like mean and standard deviation of market capitalization and dividend paid of the eight companies for the period 2010-11 to 2014-15 have been calculated. On the basis of that coefficient of variation of market capitalization of the companies has been calculated and corresponding rank has been given. As coefficient of variation is the parameter of variability, Tech Mahindra shows the highest level of variation in market capitalization over the aforementioned period., while Mphasis shows lowest variability in the value of market capitalization.The same calculation has been carried out in case of dividend paid. Tech Mahindra shows highest degree of variability among all the eight companies, while Infosys shows lowest degree of variation in dividend paid. Now, on the basis of the rank of the companies in terms of variability in dividend paid and in market capitalization, Spearman's rank correlation has been obtained. It shows moderately high level of correlation between the variability of market capitalization and dividend paid.

\subsection{Third level analysis}

From the descriptive statistics, the year on year growth rate of all the eight companies have been obtained in terms of market capitalization and dividend paid. On the basis of the growth rate obtained in terms of market capitalization and dividend paid, all the eight companies given rank.On the basis of this rank, Spearman's correlation coefficient has been obtained. It also shows moderately high level of correlation exists between market capitalization growth rate and dividend growth rate. Thus, from all the three levels of analysis, it can be established that market capitalization is one of the most important factors on which dividend payout depends. That means market capitalization should be used as an important variable in calculating and predicting dividend policy of the company. The reverse is also true.

\section{Limitations \& Future Directions}

In this paper, relationship between dividend paid and market capitalization has been established.From different perspectives like absolute relationship and relationship of growth as well as on variation.For this purpose top eight IT companies details in terms of market capitalization and dividend payout were collected for the last five years. Initially it was thought that total ten companies would be considered for this paper but later the names of two companies were omitted due to lack of data. The result obtained from the analysis of this paper is quite helpful in giving an overview of the said relationships, but this result may not be concrete. To get concrete result, some more companies' details should be analyzed for longer period. At the same time, from statistical point of view multidimensional and multivariate method are more useful than ordinary correlation and rank correlation.

\section{References}

[1]. Bruce I Jacobs and Kenneth N Levy, Investment Analysis: Profiting from a Complex Equity Market, John Wiley \& Sons, 1998 edited By Frank J. Fabozzi.

[2]. Corporate Payout Policy and Market Capitalization: Evidence from Pakistan *Mian Sajid Nazir, Allah Rakha, Muhammad Musarrat Nawaz, Journal of Economics and Behavioral Studies. 
[3]. Owino Odhiambo John, The Effect Of Dividend Payout Ratio On Market Capitalization Of Firms Listed On The Nairobi Securities Exchange

[4]. Handbooks in operations research and management science: Finance Edited by Robert A. Jarrow, Vojislav Maksimovic, W. T. Ziemba , Elsevier, 1995 , UK, On the Predictability of Common Stock Returns: World Wide Evidence, By Gabriel Hawawini \& Donald B Keim

[5]. African Journal of Business Management Vol.3 (5), pp. 220-226, May 2009 , The impact of share market capitalization on a company's performance: A case study in the Nigerian confectionary industry By Oluwatoyin, Matthew and Gbadebo, Olusegun Odularu

[6]. Lina Zaghloul Bichara Institutional Ownership and Dividend Policy: A Framework Based on Tax Clientele, Information Signaling and Agency Costs

[7]. Vinay Kandpal , P C Kavidayal, A Study Of Dividend Policy And Its Effect On Market Value Of Shares Of Selected Banks In India , IOSR Journal of Business and Management (IOSR-JBM) e-ISSN: 2278-487X, p-ISSN: 2319-7668. Volume 17, Issue 1.Ver. I (Jan. 2015), PP 41-44

[8]. Lilian Luvembe, Mungai John Njangiru, Dr. Eddie Simiyu Mungami, Effect of Dividend Payout on Market Value of Listed Banks in Kenya, International Journal of Innovative Research and Development, ISSN 2278 - 0211 (Online), volume 3 issue 11 (November 2014)

[9]. Abdullah Al Masum, Global Disclosure of Economics and Business, Volume 3, No 1 (2014) ISSN 2305-9168, Dividend Policy and Its Impact on Stock Price - A Study on Commercial Banks Listed in Dhaka Stock Exchange

[10]. NTUI Ponsian, Kawiche Prosper, Thadeo Yuda, Godfrey Samwel, Archives of Business Research- Vol.3,No.3 Publication Date: June 25, 2015 DOI: 10.14738/abr.33.1118 (Society for Science and Education) ISSN: 2054-7404, Relationship between Dividend Policy and Share Price

[11]. Syed Akif Shah , Umara Noreen , International Journal of Economics and Financial Issues 2016, 6(2), 461-472. ISSN: 2146-4138 , Stock Price Volatility and Role of Dividend Policy: Empirical Evidence from Pakistan

[12]. Pushpa Bhatt and Sumangala JK, Journal of Finance, Accounting and Management, 3(2), 1-14,July 2012, Impact of Earnings per share on Market Value of an equity share: An Empirical study in Indian Capital Market 